\title{
Perwujudan Pendidikan Karakter Pada Era Kontemporer Berdasarkan Perspektif Ki Hajar Dewantara
}

\author{
Devin Akbar Albany \\ Universitas Sriwijaya \\ vinalbg@gmail.com
}

\begin{abstract}
Abstrak
Pendidikan tentunya merupakan salah satu komponen penting yang sangat berpengaruh bagi Indonesia, karena pendidikan merupakan proses memanusiakan manusia. Adanya pendidikan di Indonesia tidak lain untuk menciptakan generasi penerus yang berkarakter mulia serta memiliki kualitas. Dalam mewujudkan generasi yang diharapkan ini salah satunya adalah dengan pendidikan karakter. Nilai-nilai kepribadian yang baik dapat dituangkan kepada peserta didik melalui pendidikan karakter ini. Nilai-nilai kepribadian yang harus diwujudkan oleh pendidikan karakter tersebut meliputi jujur, sopan santun, cerdas dan berjiwa kepemimpinan. Salah satu tokoh pendidikan terkenal di Indonesia, Ki Hajar Dewantara mempunyai pemikiranpemikiran yang sangat berpengaruh terhadap dunia pendidikan di Indonesia. Banyak kontribusi yang beliau berikan untuk memajukan pendidikan, termasuk pendidikan karakter di Indonesia. Pada artikel ini membahas pemikiran-pemikiran Ki Hajar Dewantara tersebut yang dapat diterapkan pada pendidikan karakter era kontemporer atau era digital saat ini. Pembuatan artikel ini didasari oleh hasil studi dengan cara mengumpulkan sumber referensi dan menganalisa berbagai sumber referensi berdasarkan metoda atau pendekatan literatur dari berbagai sumber, untuk menjaga keakuratan data dan hasil yang baik.
\end{abstract}

Kata Kunci: Pendidikan Karakter, Kontemporer, Ki Hajar Dewantara.

\begin{abstract}
Education is certainly one of the most important components that are very influential for Indonesia, because education is a humanizing process. The existence of education in Indonesia is nothing but to create the next generation with noble character and quality. In realizing this expected generation, one of them is through character education. Good personality values can be poured into students through this character education. The personality values that must be realized by character education include honesty, courtesy, intelligence and leadership spirit. One of the well-known educational figures in Indonesia, Ki Hajar Dewantara has thoughts that are very influential on the world of education in Indonesia. He made many contributions to advancing education, including character education in Indonesia. This article discusses Ki Hajar Dewantara's thoughts which can be applied to character education in the contemporary era or the current digital era. This article is based on the results study by collecting reference sources and analyzing various reference sources based on methods or literature approaches from various sources, to maintain data accuracy and good results.
\end{abstract}

Keywords: Character Education, Contemporary, Ki Hajar Dewantara. 


\section{Pendahuluan}

Pendidikan merupakan suatu usaha sadar dan terencana dalam membangun suasana belajar dan proses pembelajaran kepada peserta didik guna menciptakan peserta didik yang mengalami perubahan kearah yang lebih maju. Pendidikan mencakup aspekaspek penting, seperti ilmu pengetahuan dan kecerdasan, budi pekerti dan kepribadian, sosial dan kewarganegaraan, serta spiritual dan kesehatan (Prayitno dan Manullang, 2011). Sekolah sebagai lembaga pendidikan formal tentunya harus bisa mengemban semua beban pendidikan tersebut. Sekolah merupakan tempat dimana terjadinya proses memanusiakan manusia, tempat menghasilkan manusia yang memiliki daya saing, serta menciptakan kader bangsa yang berkualitas (Heri, 2012). Terlebih lagi jika dikaitkan dengan perkembangan teknologi yang akhir-akhir ini sangat pesat. Selain memiliki kecerdasan tinggi untuk bertahan di dunia serba maju ini, dibutuhkan pula karakter yang kokoh dalam menghadapi kemajuan agar tidak terjerumus ke dalam jurang kesengsaraan.

Era kontemporer atau yang dikenal dengan era digital merupakan suatu masa dimana segala aspek dalam kehidupan telah mengalami berbagai macam perkembangan pesat menjadi serba digital. Jika dilihat sekilas, perkembangan ini berdampak baik karena dapat memudahkan kehidupan manusia. Namun nyatanya di negeri ini, justru berbagai macam masalah nasional semakin marak terjadi dengan tiada hentinya. Kemajuan teknologi yang seharusnya disambut baik oleh masyarakat malah menjadi ladang kriminalitas yang baru. Masuknya budaya asing dengan mudah ke dalam negeri juga merupakan dampak dari era digital sekarang. Budaya negatif yang masuk ke Indonesia sering mempengaruhi kalangan pelajar karena minimnya pengetahuan mereka untuk membendung hal negatif tersebut. Negara kita juga rentan akan kejahatan yang mengancam stabilitas dan kedaulatan negara, seperti spionase, sabotase, terorisme dan aksi-aksi kejahatan lainnya (A, 2010; Muslich, 2011). Dari dampak-dampak negatif di atas banyak yang terjadi karena minimnya moral di negara kita. Maka dari itu, dibutuhkan pendidikan moral yang dapat membina dan membangun kepribadian para masyarakat di Indonesia, yang lebih lanjut dikenal dengan sebutan pendidikan karakter.

Pendidikan karakter memang sudah lama dijalankan di negara kita. Namun, semakin berjalannya waktu dan berkembangnya zaman, pendidikan karakter ini semakin lama kian memudar. Bahkan kemajuan teknologi sering membuat pendidikan 
yang berfokus pada kecerdasan lebih diutamakan ketimbang pendidikan karakter. Secara tidak langsung, kurangnya karakter masyarakat suatu negara dapat mengancam negara itu sendiri. Negara tersebut akan menjadi lebih mudah dipecah belah, mudah untuk diadu domba, serta rentan untuk dikuasai oleh negara lain yang berujung terpecahnya suatu negara.

Ki Hajar Dewantara adalah seorang pahlawan dalam bidang pendidikan. Banyak pemikiran yang ia tuangkan demi kelangsungan dan kemajuan pendidikan di negara Indonesia. Bahkan ia diberi gelar sebagai Bapak Pendidikan Indonesia karena sangat banyaknya kontribusi yang ia berikan dalam dunia pendidikan Indonesia. Selain gagasannya mengenai sistem pendidikan, ia juga sering mengemukakan pemikirannya tentang pendidikan karakter. Ia banyak memberikan gambaran mengenai contoh-contoh pendidikan karakter yang dapat diimplementasikan sekolah-sekolah kepada para peserta didiknya. Hal ini tidak lain sebagai besarnya bentuk kepedulian Ki Hajar Dewantara terhadap karakter anak bangsa (Dewantara, 2004).

Kajian tentang pendidikan dengan berbagai perspektif yang berkaitan dengan KI Hajar Dewantara sudah banyak dilakukan, tetapi pembahasan yang khusus mengkaitkan dengan situasi kontemporer belum dilakukan (Suwahyu, 2018; Subekhan \& Annisa, 2018; Utami, 2017; Adpriyadi, 2018). Penelitian tersebut secara umum lebih bayak menekankan tentang konsep pendidikan karakter yang dicetuskan oleh Ki Hajar Dewantara. Keberbedaan dengan penelitian ini pada aspek keterkaitan pendidikan karakter paa situasi kontemporer saat ini. Kajian ini dapat memberi gambaran secara umum bagaimana pendidikan karakter berdasarkan perspektif Ki Hajar Dewantara berkontribusi bagi pembentukan karakter dewasa ini. Tujuan penelitian ini adalah memahami pendidikan karakter berdasarkan perspektif Ki Hajar Dewantara tersebut dapat diimplementasikan ke dalam kehidupan sekarang, yaitu pada era kontemporer atau era digital. Penulis akan menjelaskan lebih lanjut tentang perwujudan pendidikan karakter pada era kontemporer berdasarkan perspektif Ki Hajar Dewantara.

\section{Metode Penelitian}

Metode yang digunakan kajian ini menggunakan studi pusaka atau literatur (Zed, 2008). Penulisan mengacu kepada beberapa sumber literatur, yaitu jurnal pendidikan, ebook, artikel, makalah, internet, dan sumber-sumber lainnya. Data yang dilampirkan 
pada penelitian ini didapatkan dari berbagai sumber yang terpecaya setelah dilakukan pengkajian materi perwujudan pendidikan karakter pada era kontemporer berdasarkan perspektif Ki Hajar Dewantara. Teknik analisis data yang digunakan adalah teknik analisis model interaktif. Analisis model interaktif meliputi tiga kompenen penting, yakni reduksi data, penyajian data, dan penarikan kesimpulan (Miles dan Huberman, 1992)

\section{Pembahasan}

\section{A. Biografi Ki Hajar Dewantara}

Raden Mas Suwardi Suryaningrat atau yang lebih dikenal dengan panggilan Ki Hajar Dewantara lahir pada 2 Mei 1889 di Yogyakarta. Beliau berasal dari keluarga bangsawan keraton Puro Pakualaman, Yogyakarta. Beliau adalah anak dari Kanjeng Pangeran Haryo Suryaningrat dan Raden Ayu Sandiyah. Ayahnya merupakan anak dari Kanjeng Gusti Hadipati Haryo Suryosasraningrat yang bergelar Sri Paku Alam III. Saat masih kecil, ia kerap disapa sebagai "Denmas Jemblug" yang artinya buncit, hal ini dikarenakan sewaktu bayi, perutnya buncit (Dewantara, 2004; Mestoko, 1986).

Selain berasal dari keturunan bangsawan, Suwardi Suryaningrat juga lahir dalam garis keturunan ulama, karena beliau adalah keturunan dari Sunan Kalijaga. Dengan demikian, beliau besar dalam lingkungan sosio kultural dan religius. Ia banyak menerima ajaran-ajaran yang bernilai agama dari ayahnya. Selain itu, hidup di keluarga bangsawan merupakan salah satu keberuntungan bagi anak anak pada masa itu. Dengan kesempatan tersebut, Ki Hajar Dewantara dapat mengenyam pendidikan yang layak dan berkecukupan. Ia bersekolah di sekolah dasar milik Belanda Europeesche Lagere School (ELS), lalu dilanjutkan ke sebuah sekolah guru di Yogyakarta, Kweekschool. Ia pun pernah menjalani pendidikan di sekolah dokter di Jakarta, yaitu STOVIA (School Fit Opleiding Van Indische Artsen) dengan beasiswa. Namun, pada tahun kelima kondisi kesehatannya memburuk, sehingga beasiswa tersebut dicabut. Akan tetapi, dibalik pencabutan beasiswa tersebut dan dikeluarkannya Suwardi dari STOVIA lebih bersifat politis. Kejadian tersebut terjadi sesaat setelah Suwardi membacakan sebuah sajak yang mendeskripsikan keperwiraan panglima perang andalan Diponegoro, yang bernama asli Sentot Prawirodirdjo (Utami, 2017). 
Setelah lepas dari STOVIA, ia mendapatkan Surat Keterangan Istimewa karena kemahirannya dalam berbahasa Belanda. Beliau sempat menjadi jurnalis pada surat kabar Sedyotomo yang berbahasa Jawa dan surat kabar berbahasa Belanda Midden Java di Yogyakarta serta De Exspress di Bandung. Suwardi Suryaningrat pernah menjalani pengasingan di Belanda. Pada saat itu, ia bergabung dalam organisasi pelajar asal Indonesia, Indische Vereeniging (Perhimpunan Hindia). Pengetahuan dan pemahamannya akan sosial pendidikan terus berkembang karena ilmu yang ia dapatkan dari Dalton, Frobel, Montessori, pesantren, dan asrama. Ia mulai membangun cita-citanya untuk memajukan pendidikan masyarakat Indonesia sejak tahun 1913, saat ia mendirikan kantor berita Indonesia "Indonesisch Pers-bureau". Dalam mendirikan berbagai lembaga pendidikan di Indonesia, Suwardi Suryaningrat terbantu oleh Europeesche Akta, sebuah ijazah bergengsi di Belanda yang ia miliki.

Sejak berusia 40 tahun, Ia tak lagi menggunakan nama Suwardi Suryaningrat. Ia menggantinya dengan Ki Hajar Dewantara seperti yang kita kenal seperti saat ini. Ia menanggalkan gelar bangsawan di depan namanya agar dapat bebas dekat dengan masyarakat. Ki Hajar Dewantara wafat pada tanggal 26 April 1959 di Mujamuju, Yogyakarta. Ia dimakamkan di makam Wijaya Brata Yogyakarta. Pada tanggal 28 November 1959, dilaksanakan upacara pemakamannya. Upacara tersebut dipimpin oleh Panglima Kodam Diponegoro Kolonel Soeharto. Lalu, Ki Hajar Dewantara ditetapkan oleh pemerintah sebagai Pahlawan Nasiona; pada tanggal 16 Desember 1959. Hari lahirnya juga ditetapkan sebagai Hari Pendidikan Nasional berdasarkan Keputusan Presiden RI Nomor 316 Tahun 1959. Ki Hajar Dewantara dikenal sebagai sebagai tokoh yang kreatif, jujur, sederhana. berani dan konsisten sehingga beliau dihormati dan disegani baik oleh kawan maupun lawan.

\section{B. Pendidikan Karakter pada Era Kontemporer}

Pada dasarnya, penyelenggaraan pendidikan berkaitan erat dengan penanaman nilai-nilai luhur. Pola dan proses pendidikan memang dianjurkan untuk mengembangkan serta menyadarkan peserta didik terhadap nilai-nilai moral, seperti kejujuran, kebaikan, kebenaran, kasih sayang dan nilai lainnya. Nilai-nilai tersebut merupakan nilai-nilai universal dimana dimiliki oleh semua agama (Suseno, 1997). Selain itu, pendidikan juga digunakan dalam memperkokoh keyakinan seseorang 
secara spesifik sesuai agama yang dianutnya. Untuk menciptakan pendidikan semacam itu, hendaknya selalu berdasarkan atau diintegrasikan terhadap nilai-nilai universal agama., karena sejatinya pendidikan menginginkan terciptanya manusia yang berbudi pekerti luhur, berkepribadian dan berkarakter sehingga disamping ilmu yang ia dapat dan kuasai, ia juga memiliki jiwa yang diyakini dapat membawa ilmu ditangannya kelak agar dapat bernilai positif untuk dirinya maupun sesama manusia lain.

Nilai moral adalah nilai-nilai integritas hidup seseorang terkait dengan tindakan baik dan buruk yang memandu kehidupan serta pilihannya secara umum. Dengan nilai moral seseorang dapat mengontrol dirinya agar tetap berkarakter yang baik. Disinilah peran pendidikan untuk menanamkan nilai-nilai yang ada tersebut kedalam batin dan tingkah laku manusia (Majid, 2010). Pendidikan semacam ini telah membantu banyak orang untuk membedakan apa yang baik dan apa yang tidak baik, apa yang harus diprioritaskan dan apa yang tidak harus diprioritaskan, serta apa yang perlu dan apa yang tidak perlu.

Pendidikan nilai secara mutlak hanya dapat direalisasikan atau dipaparkan dalam suatu kebersamaan. Dimana dalam kebersamaan tersebut terdapat rasa empati dan kekeluargaan (Zuriah, 2007). Jadi, hampir tidak mungkin tampaknya untuk melaksanakan pendidikan nilai moral tanpa ada rasa empati sedikitpun untuk menghargai sesamanya, menghargai lingkungan alam dan sosialnya, serta memusat kepada penghargaan terhadap kehidupannya. Sementara itu, empati sendiri muncul karena adanya dorongan untuk menghadapi persoalan-persoalan dengan batas-batas perbedaan, seperti ras, etnis, golongan, agama dan batas-batas perbedaan lainnya (Adisusilo, 2014).

Pada era kontemporer (digital) ini, istilah pendidikan nilai lebih sering dikenal dengan sebutan pendidikan karakter. Kata karakter sendiri berasal dari bahasa Inggris Character yang juga berasal dari bahasa Yunani. Kata tersebut pada awalnya digunakan untuk menandai hal-hal yang mengagumkan dari dua keping koin. Lebih lanjut, istilah ini digunakan untuk menandai dua hal yang berbeda satu sama lainnya, dan akhirnya digunakan untuk membedakan kualitas pada setiap orang (Muin, 2011). Kata karakter pun memiliki arti yang mirip dengan kata Akhlaq dalam bahasa Arab. Dalam bahasa Arab, kata Akhlaq merupakan bentuk jamak dari kata Khuluq yang 
berarti budi pekerti, tabiat, kebiasaan, kesatriaan, kejantanan. Kedua kata ini memang memiliki kesamaan satu sama lain, yaitu sama-sama menunjukkan kepribadian seseorang, seperti apa dirinya, baik dan buruknya, perilaku dan kehidupannya, serta hubungannya dengan sesama manusia lain (Majid, 2010).

Menurut Masnur Muslich, karakter merupakan nilai-nilai budi pekerti manusia yang memiliki hubungan dengan Tuhan Yang Maha Esa, dirinya sendiri, lalu kepada sesamanya, lingkungan sekitarnya, dan kebangsaan yang diwujudkan dari dalam dirinya seperti sikap, akal, perasaan, lalu menuju perkataan dan perbuatan berdasarkan norma agama, hukum, tata krama dan tata budaya, serta adat istiadat (Muslich, 2011). Sedangkan dalam Kamus Besar Bahasa Indoensia karakter diartikan sebagai watak, tabiat, kepribadian dan kejiwaan, serta akhlak atau budi pekerti yang dapat digunakan sebagai pembeda antara seseorang dengan yang lainnya (Poerwadarminta, 1999). Berdasarkan pendapat dari dua pakar di atas, dapat disimpulkan bahwa karakter adalah sesuatu yang ada pada tiap individu yang menjadi ciri kepribadiannya sendiri karena berbeda dengan individu lainnya. Perbedaan kepribadian tersebut berguna untuk menjalankan kehidupan dan saling bekerja sama, baik itu dari ruang lingkup kecil seperti keluarga, sampai ke ruang lingkup besar seperti bangsa dan negara.

Istilah karakter juga dapat dimaknai dari dua sisi pengertian, yaitu deterministik dan dinamis. Secara deterministik, karakter dipahami sebagai sekumpulan kondisi rohaniah yang sudah teranugerahi pada diri individu sejak dulu (given). Artinya, karakter disini hanya bisa kita terima begitu saja dan tidak bisa kita ubah lagi. Sifat karakter dalam hal ini adalah tetap, karenanya menjadi pembeda khusus antara satu individu dengan individu yang lain. Lalu secara dinamis, karakter dipahami sebagai seberapa besar tingkat kekuatan individu dalam upayanya mengatasi kondisi rohaniah yang bersifat given, sehingga kondisi tersebut berubah seiring proses yang dikehendaki oleh individu tersebut (willed) guna menyempurnakan kemanusiaannya (Asmani, 2012).

Seperti yang sudah dijelaskan sebelumnya, karakter seseorang diasah dan dididik salah satunya pada pendidikan karakter. Menurut Lickona pendidikan karakter merupakan bentuk usaha yang diberikan secara sengaja untuk membentuk kepribadiannya agar ia dapat mengimplementasikan nilai-nilai moral dan etika yang baik kedalam kehidupannya (Lickona, 1991). Selanjutnya, Lickona membagi tiga 
komponen karakter yang baik yaitu, pengetahuan moral, perasaan moral, dan tindakan moral. Kesemua komponen tersebut tentunya akan terlatih dengan pengetahuan akan hal-hal yang baik dan benar. Kemudian akan ada rasa tenang yang timbul bagi setiap insan sebagai efek pengetahuan tersebut. Alhasil, lama kelamaan akan muncul keinginan untuk selalu menerapkannya dalam kehidupan sehingga menjadi kebiasaan. Dari sinilah kepribadian baik dapat terbentuk dengan sendirinya. Pendidikan karakter yang tepat akan menciptakan manusia yang berjiwa baik dalam hubungannya baik itu terhadap Tuhan maupun terhadap sesama manusia (Lickona, 1991).

Tak dapat dipungkiri pada era digital sekarang perkembangan teknologi menjadi sangat pesat. Hal ini juga semakin memicu informasi yang menyebar begitu cepat. Berkembangnya teknologi juga semakin digaungkan untuk memudahkan setiap pekerjaan manusia. Namun, kemajuan ini tak selalu membawa dampak positif bagi kehidupan manusia. Justru, dampak negatif yang diakibatkan dari kemajuan ini sangat banyak terlihat bahkan pada kalangan remaja. Perkembangan globalisasi yang seharusnya dimanfaatkan dengan baik dan benar malah menjadi sesuatu yang disalahgunakan (Suyanto, 2000). Dengan teknologi yang serba bisa seperti saat ini terkadang membuat para pelajar menjadi malas dan sangat bergantung pada teknologi itu sendiri. Masuknya informasi apapun dengan cepat juga tidak dapat disaring oleh para remaja yang tidak bisa mengontrol dirinya sendiri. Termasuk juga masuknya budaya asing yang bertentangan dengan nilai-nilai bangsa pun dengan mudah merasuki remaja di negeri ini. Maka dari itu, perlunya pengawasan dan kontrol terhadap para remaja agar mereka memiliki kepribadian yang baik untuk menyaring sendiri dampak dari kemajuan globalisasi ini. Dan disinilah dibutuhkannya pendidikan karakter yang mampu mendorong para remaja terkhusus pelajar agar tidak terpengaruh dampak-dampak negatif era digital sekarang.

\section{Implementasi Pemikiran Ki Hajar Dewantara Terhadap Pendidikan Karakter Era Kontemporer}

Ki Hajar Dewantara adalah seseorang yang menjadi tokoh penting dalam pendidikan di Indonesia. Banyak pemikiran yang ia tuangkan demi kemajuan dan keberhasilan pendidikan di negeri ini. Beberapa pemikiran yang ia sampaikan juga menyorot pendidikan karakter, karena baginya karakter para anak bangsa sangatlah 
penting untuk tetap dijaga agar terbentuk generasi-generasi penerus bangsa yang baik. Berikut adalah beberapa pemikiran Ki Hajar Dewantara berkaitan dengan pendidikan karakter yang dapat diimplementasikan kedalam era kontemporer saat ini.

\section{Teori Trikon}

Menurut Ki Hajar Dewantara, pendidikan merupakan proses enkulturisasi. Artinya, pendidikan menjadi suatu upaya untuk menanamkan nilai-nilai budi pekerti luhur kepada generasi-generasi penerus bangsa. Penanaman nilai-nilai ini bertujuan untuk mempertahankan, mengembangkan, serta memajukan kebudayaan menuju ke arah keluhuran dalam berkehidupan kemanusiaan.

Upaya enkulturasi dalam pendidikan ini dapat dijalankan dengan tiga unsur yang dikenal dengan istilah Teori Trikon, yaitu kontinuitas, konvergen dan konsentrisitas. Kontinuitas berarti kebudayaan asli Indonesia yang sifatnya dilestarikan dari alam kita haruslah bersifat continue, tetap bersambung terus menerus secara berkesinambungan. Dengan kesinambungan ini membuat budaya tetap terjaga dari generasi ke generasi sehingga mampu bertahan walaupun terjadi perubahan zaman yang signifikan. Teori ini dibutuhkan pada era kontemporer sekarang mengingat mudahnya masuk budaya asing yang bertentangan dengan budaya asli Indonesia di kalangan para pelajar. Teori ini dapat membendung dan mengontrol pelajar agar selalu bangga dengan budaya sendiri sehingga tidak mudah terpengaruh beberapa budaya negara luar yang berdampak negatif bagi bangsa Indonesia (Yamin, 2008).

Selain kebudayaan asing yang bertentangan dengan Indonesia, ternyata masih ada kebudayaan asing yang dipandang dapat berdampak positif bagi negara Indonesia. Hal inilah yang dituang dalam teori konvergen yang menjelaskan bahwa dalam upaya mengembangkan kebudayaan asli Indonesia, harus juga memadukannya dengan budaya-budaya negara luar yang dianggap dapat memajukan budaya Indonesia. Ini bertujuan agar terciptanya karakter dunia sebagai kesatuan kebudayaan umat secara universal (konvergen) tanpa menghapus atau menjatuhkan kebudayaan dan identitas bangsa masing-masing.

Teori yang terakhir adalah konsentrisitas. Artinya bahwa dalam upaya mengembangkan kebudayaan asli Indonesia, haruslah bersikap terbuka, akan tetapi tetap kritis dalam bertindak dan selektif dalam memilah kebudayaan asing agar tidak menjadi pengaruh buruk di negara kita. Hal ini bertujuan agar kita dapat tahu seperti 
apa budaya negara luar yang mungkin dapat membawa Indonesia lebih maju, tanpa khawatir akan jatuhnya moral bangsa (Elmubarok, 2007).

Dari ketiga teori diatas, secara khusus memandang bahwa budaya Indonesia sebagai identitas dan jati diri bangsa memang harus dipertahankan karena banyak memiliki nilai-nilai moral dan budi pekerti di dalamnya. Terlebih di era sekarang, kemajuan teknologi tak jarang dibarengi dengan kemajuan budaya dan pola hidup manusia. Tentunya, Indonesia tidak bisa menolak kemajuan ini dan harus menerima karena tuntutan globalisasi. Namun, dengan ketiga teori tersebut memungkinkan kita tetap mengenal seperti apa kehidupan di negara luar tanpa perlu takut terpengaruh akan budaya asing sehingga kita dapat menilai apa yang kurang dari budaya kita untuk diperbarui demi kemajuan bangsa ini sendiri.

\section{Trilogi Kepemimpinan}

Pemikiran ini adalah yang paling dikenal di kalangan masyarakat, terkhusus pelajar. Ajaran tentang kepemimpinan ini adalah Ing Ngarsa Sung Tuladha, Ing Madya Mangun Karsa, Tut Wuri Handayani. Pemikiran Ki Hajar Dewantara ini secara spesifik mengatur seperti apa seorang pemimpin, bagaimana kelakuannya, bagaimana sifatnya, serta bagaimana ia harus menjadi panutan dan contoh bagi anak buahnya. Pada era kontemporer saat ini, marak terjadi kasus pemimpin yang tidak amanah terhadap rakyatnya seperti terjadinya korupsi dan lain sebagainya. Hal ini karena mereka hanya sibuk memperkaya diri sendiri mengingat dunia sekarang lebih maju dan seolah-olah memaksa uang adalah segalanya. Mereka lebih mementingkan kepentingan pribadi dari pada kepentingan seluruh golongan. Jadi, memang sepatutnya pemikiran Ki Hajar Dewantara tentang ajaran kepemimpinan ini tetap dijalankan dalam kehidupan berbangsa dan bernegara (Dewantara, 2004).

Ing Ngarsa Sung Tuladha, memiliki arti di depan memberi teladan. Seorang pemimpin harus memiliki kepribadian dan perilaku yang baik agar dapat menjadi contoh bagi para pengikutnya. Pemimpin diibaratkan sebagai lokomotif paling depan dari kereta api. Ia yang mengarahkan puluhan lokomotif lain di belakangnya agar tetap berada pada rel yang tepat (Dewantara, 2004).

Ing Madya Mangun Karsa, artinya di tengah membangun kehendak atau niat. Pemimpin semestinya juga bisa berada di tengah-tengah anggotanya untuk membangkitkan semangat kerja dan juang (Dewantara, 2004). 
. Pemimpin dalam kepemimpinannya tidak perlu menjadi orang yang melakukan setiap pekerjaan, namun biarkan para anggota yang bekerja dibawah kendali sang pemimpin. Yang memang diperlukan adalah pemimpin tetap mengontrol dan membangun semangat para anggotanya serta memastikan lingkungan kerjanya berada pada tingkatan yang baik, tidak menurun performanya, tidak menjadi bosan dan tidak menciptakan suasana malas. Pemimpin dan anggotanya tentu memiliki tujuan yang sama, maka dari itu, pemimpin harus bisa membaur dengan anggotanya untuk membangun niat, kehendak dan kebersamaan agar cita-cita yang diinginkan tercapai.

Tut Wuri Handayani, yang berarti di belakang memberikan dorongan dan kekuatan. Pemimpin juga harus bisa menempatkan dirinya di posisi paling belakang untuk mendorong anggotanya agar kembali memiliki semangat kemajuan dan kesuksesan (Dewantara, 2004). Menjadi posisi belakang bukan berarti pemimpin melepas jabatannya karena takut serta ingin dilindungi bawahannya, namun terkadang ia harus turun melihat kondisi-kondisi bawahannya bahkan lebih membaur seperti rakyat biasa agar dapat merasakan dan mempelajari situasi yang terjadi di anggota yang ia pimpin. Dengan demikian, pemimpin dapat mengatur strategi untuk mendobrak semangat anggotanya kembali sehingga tujuan yang diimpikan tetap tercapai.

Karakter seorang pemimpin adalah karakter yang dimiliki hanya pada segelintir orang, mengingat beratnya menjadi seorang pemimpin tersebut. Menjadi pemimpin berarti kita siap menjadi contoh dan panutan, siap akan tantangan dan rintangan, siap akan pengorbanan dan siap akan jati diri yang mungkin rentan dijatuhkan. Pemimpin harus dapat memiliki kepribadian yang paling baik diantara kumpulan manusia lainnya. Dari sinilah diperlukan pendidikan karakter untuk mengajarkan nilai-nilai keprbadian kepada calon pemimpin di masa depan, terkhusus di era sekarang yang minim akan pemimpin yang memegang amanah dengan sepenuh hati.

\section{Sistem Among}

Pemikiran Ki Hajar Dewantara kali ini dilatarbelakangi oleh sistem pendidikan barat. Sistem barat memiliki dasar-dasar yaitu regering, tucht, dan orde (perintah, hukuman dan ketertiban) (Dewantara, 2004). Tentunya, sistem ini rentan menyebabkan kerusakan pada budi pekerti anak karena seolah-olah anak mendapat pemerkosaan terhadap kehidupan batinnya. Adanya hukuman setelah perintah juga 
menyebabkan sang anak selalu hidup di bawah paksaan kolonial. Begitulah yang dipikirkan Ki Hajar Dewantara. Ia menilai jika bangsa kita meniru sistem pendidikan barat tersebut, maka tentu akan merusak kepribadian seseorang. Disinilah muncul pemikiran mengenai sistem pendidikan yang dapat menjunjung tinggi suka cita dan mengedepankan upaya mendorong kekuatan pikiran dan kepribadian anak, sehingga anak dapat menjadi insan yang berguna budi pekertinya tanpa harus dipaksa serta dibawah tekanan pendidik. Sistem inilah yang dikenal sebagai sistem among.

Pada dasarnya, sistem among berarti sebuah upaya memberikan kebebasan belajar kepada anak untuk mengenal dan memahami sesuatu yang bernilai baik dari pengalamannya sendiri. Pendidik dalam hal ini tidak langsung melepas peserta didik begitu saja, namun ia tetap mengawasi dan mengontrol perkembangan kepribadian peserta didiknya. Pendidik juga memiliki peranan penting dalam mendidik peserta didiknya agar memiliki kualitas yang diharapkan. Sesuai dengan semboyan yang telah dibahas sebelumnya yaitu Ing Ngarsa Sung Tuladha, Ki Hajar Dewantara menggambarkan pendidik memiliki fungsi utama sebagai figur teladan dan panutan, baru fungsi lainnya seperti tenaga pengajar ilmu pengetahuan

Tujuan dari sistem among, buah hasil pikiran Ki Hajar Dewantara ini adalah menciptakan manusia merdeka. Artinya insan yang merdeka baik secara fisik, mental, maupun rohaninya. Tentunya, dengan sistem among yang bersifat bebas bereksplorasi ini secara cepat atau lambat dapat membentuk manusia merdeka, berbeda dengan sistem barat yang bersifat kolonial. Lebih lanjut, Ki Hajar Dewantara menginginkan tiap siswa mampu mengembangkan tiga hal penting, yaitu cipta, rasa dan karsa.

Bicara mengenai cipta, rasa dan karsa tentu tidak dapat dipisahkan dari esensi manusia dalam kehidupannya, terutama saat era digital yang memicu perkembangan revolusi industry 4.0. Di era ini tampak bahwa pendidikan dengan sistem among dengan konsep dasar cipta, rasa dan karsa tersebut sangatlah tepat untuk di terapkan. Di era digital sekarang, dunia memperoleh teknologi internet sebagai penghubung yang begitu cepat. Tidak terpikir tampaknya oleh kita bahwa akan ada suatu teknologi canggih yang dapat membuat kita berjelajah di dunia maya. Maka dari itu, sistem among buah pikiran Ki Hajar Dewantara disini hadir pada era kontemporer untuk dapat membangun manusia yang unggul dan berkualitas. 


\section{Kesimpulan}

Konsep pendidikan yang ditawarkan oleh Ki Hajar Dewantara diatas secara tidak langsung menyinggung bahwa pendidikan karakter seharusnya dapat dijalankan di setiap era, termasuk era kontemporer saat ini. Pendidikan karakter yang dapat berjalan tersebut juga semestinya mampu memberikan manfaat nyata bagi perkembangan kepribadian anak. Seperti yang Ki Hajar Dewantara gambarkan diatas bahwa dalam memperjuangkan pendidikan karakter yang sebenarnya harus ditumbuhkan dalam diri sang anak. Tentunya, pendidikan karakter sendiri tidak bisa membentuk kepribadian anak secara penuh tanpa sinergi dari pihak lainnya. Pendidikan karakter hanyalah sebagai wadah untuk membantu mendorong sang anak agar mau dan ikut dalam membentuk jati diri serta kepribadiannya. Namun sebenarnya yang menciptakan kepribadian di dalam diri sang anak tersebut tidak lain dari lingkungan keluarganya sebagai naungan awal bagi tumbuh kembangnya anak sebelum masuk ke dunia sekolah formal. Kemudian lingkungan masyarakat yang juga menjadi penentu bagaimana karakter yang dimiliki sang anak tersebut. Jika lingkungan masyarakatnya positif, maka akan mudah juga kepribadian baik tumbuh di dalam dirinya, begitupun sebaliknya.

Pada era kontemporer sekarang, seperti yang sudah dijelaskan maraknya krisis moral masyarakat. Ini juga yang menjadi penentu apakah pendidikan karakter yang sedang dijalankan berhasil atau hanya sia-sia. Ditambah lagi, sebelum negara kita berilmu, perlunya negara kita beradab. Artinya negara kita tidak akan bisa maju sebelum moral dan kepribadian bangsa sudah tertata baik terlebih dahulu. Maka dari itu, hendaknya kita melihat kembali kebelakang, bagaimana tokoh pendidikan terkenal seperti Ki Hajar Dewantara memberikan beberapa opsi dan cara mendidik dalam pendidikan karakter agar dapat kita gunakan di era kontemporer ini. Dengan demikian, kita dapat menata kembali moralitas bangsa agar terciptanya negara maju dan berkualitas serta mampu bersaing dengan negara maju lainnya di panggung dunia.

\section{Daftar Rujukan}

Adisusilo, S. (2014). Pembelajaran Nilai Karakter. Jakarta: Raja Grafindo Persada. Adpriyadi, A. (2018). Pendidikan karakter anak usia dini perspektif Ki Hajar Dewantara. Dunia Anak: Jurnal Pendidikan Anak Usia Dini, 1(1), 34-40. 
Asmani, Jamal Ma'mur. (2012). Buku Panduan Internalisasi Pendidikan Karakter di Sekolah. Yogyakarta: Diva Press.

Dewantara, Ki Hadjar. (2004). Pendidikan, Cetakan ke-3. Yogyakarta: Majelis Luhur Persatuan Taman Siswa.

Doni Koesuma A, (2010). Pendidikan Karakter: Strategi Mendidik Anak di Zaman Global. Jakarta: Grasindo.

Elmubarok, Zaim. (2007). Membumikan Pendidikan Nilai. Bandung : Alfabeta.

Gunawan, Heri. (2012). Pendidikan Karakter Konsep dan Implementasi. Bandung: Alfabeta

Lickona, Thomas, (1991). Educating for Character: How Our Schools can Teach Respect and Responsibility, New York: Bantam Books.

Majid, Abdul. (2010). Pendidikan Karakter dalam Perspektif Islam. Bandung: Remaja Rosdakarya.

Mestoko, Sumarsono, dkk. (1986). Pendidikan di Indonesia dari Jaman ke Jaman, Cetakan ke-2. Jakarta: Balai Pustaka.

Miles, Matthew B. \& Huberman, A. Michael. (1992), Analisis Data Kualitatif: Buku Sumber Tentang Metode Metode Baru, (Penerjemah Tjetjep Rohendi), Jakarta: UI Press.

Muin, Fathul. (2011). Pendidikan Karakter: Konstruksi Teoritik dan Praktik. Jogjakarta: Ar Ruzz.

Munir, Abdullah. (2010). Pendidikan Karakter. Yoggyakarta: Pedagogia.

Muslich, Masnur (2011). Pendidikan Karakter: Menjawab Tantangan Krisis Multidimensional, Jakarta: Bumi Aksara.

Prayitno dan Manullang, Belferik. (2011). Pendidikan Karakter dalam Pembangunan Bangsa. Jakarta: Grasindo.

Purwadarminta, W.J.S., (1999). Kamus Umum Bahasa Indonesia. Cetakan ke-6. Jakarta: Balai Pustaka.

Subekhan, S., \& Annisa, S. N. (2018). Eksistensi Keteladanan Pendidikan Karakter dalam Perspektif Ki Hajar Dewantara. Geneologi PAI: Jurnal Pendidikan Agama Islam, 5(1), 34-45.

Suseno, Franz Magnis. (1997). Etika Dasar: Masalah-masalah Pokok Filsafat Moral. Yogyakarta: Kanisius.

Suwahyu, I. (2018). Pendidikan Karakter Dalam Konsep Pemikiran Pendidikan Ki Hajar Dewantara. INSANIA: Jurnal Pemikiran Alternatif Kependidikan, 23(2), 192-204.

Suyanto, (2000). Refleksi dan Reformasi Pendidikan di Indonesia Memasuki Millennium Ketiga, Yogyakarta: Adi Cita Karya Nusa.

Utami, P. N. (2017). Konsep Pendidikan Karakter Menurut Ki Hajar Dewantara. Skripsi. Salatiga: IAIN Salatiga. 
Jurnal Humanitas

Vol. 7 No. 2, Juni 2021, hal. 93-107

Yamin, Moh. (2008). Menggugat Pendidikan Indonesia "Belajar dari Paulo Freire dan Ki Hadjar Dewantara. Cetakan ke-1. Yogyakarta: Ar-Ruzz Media.

Zed, Mestika. (2008). Metode Penelitian Kepustakaan. Jakarta: Yayasan Obor Indonesia.

Zuriah, Nurul. (2007). Pendidikan Moral dan Budi Pekerti dalam Persefektif Perubahan. Jakarta: Bumi Aksara. 